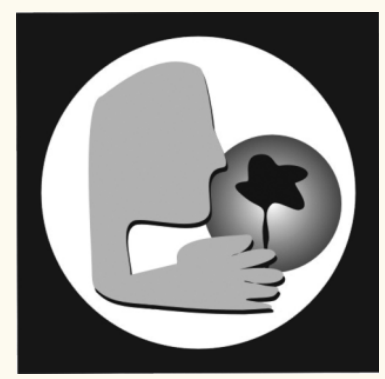

\title{
Carta das Nações Unidas
}

\author{
Letter from United Nations
}

Sustentabilidade

e $m$ Debate

Ban Ki-moon

Secretary-General

Secretary-General's message to ICID+18 on the Launch of the UN Decade for Deserts and the Fight against Desertification.

FORTALEZA, Brazil, August 17, 2010/African Press Organization (APO) Secretary-General's message to Second International Conference on Climate, Sustainability and Development in SemiArid Regions on the Launch of the UN Decade for Deserts and the Fight against Desertification.

It gives me great pleasure to send greetings to the Second International Conference on Climate, Sustainability and Development in Semi-arid Regions.

More than 2 billion people live in the world's drylands. The vast majority live on less than one dollar a day and without adequate access to freshwater. Almost three-quarters of rangelands show various symptoms of desertification. Continued land degradation - whether from climate change, unsustainable agriculture or poor management of water resources - is a threat to food security, leading to starvation among the most acutely affected communities and robbing the world of productive land.

Land degradation also poses growing social costs. Increased competition for depleted dryland resources can generate localized conflict and broader tensions. The forced migration of millions of people creates the risk of social breakdown in the traditional lands they leave behind and instability in the increasingly crowded urban areas to which they go in search of jobs, shelter and services.

These are formidable challenges. But they are not intractable. Across the globe, efforts to rehabilitate drylands are showing results. By providing sustained assistance to local communities, we can preserve or recover millions of hectares of land, reduce vulnerability to climate change and alleviate hunger and poverty for one-third of humanity.

Desertification and land degradation are global problems that require a global response. As we begin the Decade for Deserts and the Fight Against Desertification, let us pledge to intensify our efforts to nurture the land we need for achieving the Millennium Development Goals and guaranteeing human well-being. Please accept my best wishes for a successful conference.

\section{Source}

United Nations - Office of the Spokesperson of the Secretary-General http://appablog.wordpress.com/2010/08/17/secretary-generals-message-to-second-internationalconference-on-climate-sustainability-and-development-in-semi-arid-regions-on-the-launch-of-theun-decade-for-deserts-and-the-fight-against-deserti/ 